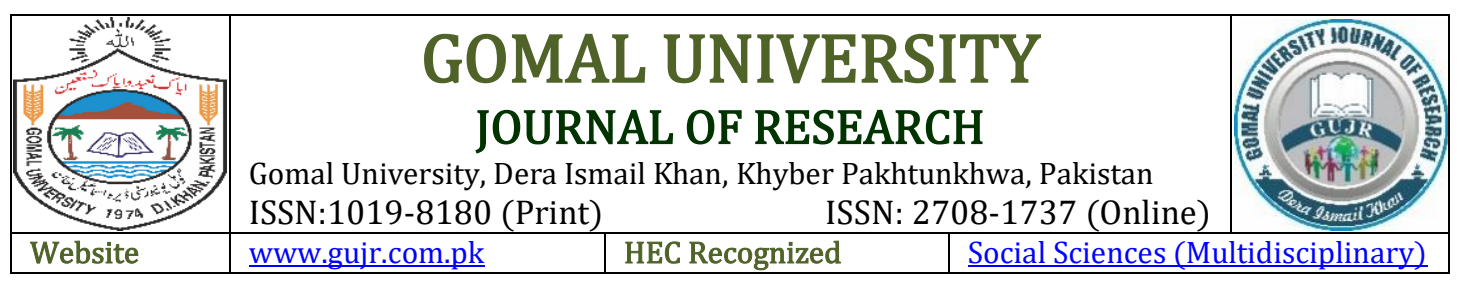

\title{
REFRAMING THE DEBATE: AGENDAS, FRAMING GOVERNANCE ISSUES AND THE POLITICS IN PMLN's GOVERNMENT FROM 2013 TO 2018
}

\author{
Salman Amin ${ }^{1}$, Ghulam Shabir² \& Saqib Riaz ${ }^{3}$ \\ ${ }^{1}$ PhD Scholar, Department of Mass Communication, AIOU, Islamabad, Pakistan \\ ${ }^{2}$ Professor, Media \& Communication Studies, University of Central Punjab, Pakistan \\ ${ }^{3}$ Asscoiate Professor/Chairman, Department of Mass Communication, AIOU, Pakistan
}

\section{\begin{tabular}{l|l} 
ARTICLE INFO & ABSTRACT
\end{tabular}}

Keywords:

Content Analysis,

English Newspaper,

General Issues, PMLN

The study aims to investigate the governance issues during regime of the Pakistan Muslim League-Nawaz (PML-N) from 2013 to 2018 in the lenses of the English Pakistani newspapers. The sole purpose is to examine that how the newspapers framed the general issues, as it is showing the performance of the government. The research design was a quantitative content analysis method and analyzing frames "Good" and "Bad" in perspective of Agenda setting level 2 "Framing Theory".

Article History:

Date of Submission:

12-05-2020

Date of Acceptance:

19-12-2020

Date of Publication:

31-12-2020 All news stories related to general issues were published in the selected Pakistani English newspapers from the (2013 to 2018) that has been analyzed. The census method applied to investigate the problem. The finding of the study revealed that the socio-economic development was not priority of an elected government and opposition parties hindered democracy by engaging it in an adversarial politics with the traditional political style. Moreover, elected democratic government was unable to uphold its pre-election promises.

\section{(c) (i) (8)}

2020 Gomal University Journal of Research

\begin{tabular}{ll}
\hline Corresponding Author & Salman Amin: salmanio2007@gmail.com \\
\hline DOI & https://doi.org/10.51380/guir-36-02-10 \\
\hline
\end{tabular}

\section{INTRODUCTION}

This study investigated the governance issues of Pakistan Muslim League Nawaz's government from the 2013 to 2018 in light of English Pakistani newspapers. The research identified agenda setting level two, i.e., Framing theory. In this study, two frames described the governance and, related to the framing theory, like the "Good" and "Bad". Over the decades, media has considered as a reliable source of information for people world. The layman explores news and data about events happening globally, and media serves as principal source. It is imperative to comprehend the diverse ways in which media frames eminent news information. Over the passage of years, media has become the most reliable information source over the globe. The people all over the world are in search of information about vital events taking place at different parts of world and 
major source providing this information is media. The several ways of media framing prominent useful news are vital to know. Framing theory says, "proposes that how idea, issue/personality is presented (framed) in the media influence how people think about that issue/personality" (Hoffert, 2018). "The news media often reframe event by stressing different attributes of event, consciously or unconsciously, in order to keep story alive and fresh" (Schildkraut \& Gruenwald, 2019). It usually happens that over high-profile news stories, the opinion and viewpoint of the different media outlets is different from one another (Knox, 2017). Mass media presentation of news and framing of the information by usage of the particular words and the images has great influence over the reality perception of the individuals about the society and the world to some extent (Scheufele, 1999; Scheufele \& Tewksbury, 2007; Pavelka, 2014, Schildkraut \& Gruenwald, 2019).

Information presented to audience in the form of news is not randomly presented, but there is whole process of careful selection by the journalists and editors i.e., the media practitioners that what and how to present any particular information. The media houses having their specific organizational policies along with the personal strategies and viewpoints of the individual media practitioners play decisive role in selection process of the news and information. "News content is product or consequence of routines, practices and values" (Riffe, Lacy, Fico \& Watson, 2019). The process followed by news organizations in order to judge events as news, whether worthy or not is known as media gatekeeping (TUTHERIDGE, 2017). What is the role of gatekeeping journalist's in today's media environment? Media is considered as the information gatekeeper of society, it is important for media to be wary and cautious about the judgment of worthiness of news, in order to educate the masses and provide correct information to the audience about the happenings in the world, especially related to those issues having their impacts on the target audience (Welbers, 2016). Media's gate-keeping role is of significance as the news selected and then framed by the media has great contribution in the mind making process of public about the issues. Tetteh and king (2011) explained the media gate-keeping effectiveness is judged by the ability of media for determining the international, national and local happenings and to present the news worthy and the information necessary in front of the audience (Chattopadhyay, 2018).

At first, there need to be a clear understanding of the term 'Governance' as various descriptions of this concept exists. Secondly, it could be evaluated for achievement of desired aims at national level. Three actors involved in this decision-making process related to politics, administration and society affecting the public. Lifestyle of a nation is determined by the governance, as how well organized it is in making and implementing decisions (politics), the mediating differences (public goods), and exercising the legal rights and obligations (public administration). In other words, it is a set of rules and practices encompassed by specific institutions for setting the limits and providing incentives. It works for all strata of society living in country. A state is considered responsible for the provision of balanced political and legal environment and the civil society is supposed to facilitate the political and social interaction in a country. Asghar, (2013) described that In Pakistan, common perception about term 'Governance' is that it is about maintenance of law-and-order situation of the country. On the contrary, it is a comprehensive concept about the management of social, political and economic affairs of the state (Adnan \& Fatima, 2018). With its intrinsic vagueness and inherent specificity lack, governance research shows multiple efforts to define it and measure it in different ways and directions (Trainor \& Subbio, 2014; Liu, 
2017). The term, governance, is like a flexible carrier, which can be employed to convey various meanings.

In this process, two paths of definitions have gradually been emerging. It is worth mentioning that academics and international agencies conceptualize governance within their interests and specific contexts. Governance is interpreted as an outcome in itself by some scholars, while a theoretical construct like a mean for promoting the sustainable development (Liu, 2017). Many approaches seek to conceptualize concept of good governance by talking various key attributes of governance, however, underlying definitions and mechanisms remain vague and minimally operational. Moreover, much scholarly attention to governance has concentrated on the World Bank's efforts to measure good governance around world as well as on multifaceted responses to World Bank's use of the concept (Lateef, 2016). For instance, according to a report of World Bank (1989), governance is one of the major crises in African continent. More specifically, such phenomena as referred by World Bank is "the extensive personalization of power, the denial of fundamental human rights, widespread corruption and incidence of unelected and unaccountable government" (Spalding, 2017). The current situation in governance terms is critical in Pakistan as both internally and externally, forces are putting pressure directly and indirectly in order to weaken governance system of Pakistan. At one end, country is fighting a war against terrorism, whereas on other side, energy crises, food crises and unemployment have become major issues of Pakistan. Almost all sectors of country are facing deterioration whether it is health, education or industry.

\section{Problem Statement}

This study had been designed to investigate the governance issues coverage of Pakistan Muslim League Nawaz's political regime (2013 to 2018) in the English Pakistani press regarding general issues. This study tries to investigate episodic as well as the thematic frames used in the coverage of general issues in the selected newspapers. This study addressed some dimensions that made use of frames i.e., the Good and Bad regarding general issues in the English press of the Pakistan because to find out how the press/media covered the issues and presented the performance of government.

\section{LITERATURE REVIEW}

Media frames reality in a patterned and predictable way and thus forms social reality. Gamson and Modigliani (1989) comment that "Media discourse is part of a process by which individuals construct meaning, and public opinion is part of the process by which journalists develop and crystallize meaning in public discourse". Priming means as " goal, intended effect, of strategic actors' framing activities." However, priming and agenda setting carry capacity of creating widespread bias. Entman (2007) defines bias as "consistent patterns in framing of communication mediated that promote influence of one side of conflicts over the use of government power" (p. 166). Most of time, the social landscape of Pakistan has been afflicted with insecurity, disease, illiteracy, and injustice. Post 9/11 incidents show how this country has been associated with the

'war on terrorism.' Several people hold the view that land of Pakistan has performed the role of a sanctuary for terrorists, but all this propaganda cannot mitigate reality that all this destruction has caused considerable damage of lives and fiscal revenue. These situations supply productive ground for rise of terrorism. If we analyse terrorist activities then come to conclusion that this act/activity, it never comes from solitary instant of stimulation rather it is a search for individual worth. 
A number of analyses of similar motivations have come into view in the current years. There are variations in the analyses concerning the kind and diversity of inspirational factors which have been recognized as vital to terrorism. A number of authors have identified only single inspiration as decisive; while others have listed a multitude of motivations (Shrestha, Williams, Samarrai, Geldermalsen \& Zaidi, 2019). The socio-economic hardships when they were united with political hardships, the end results were nothing but a damaging blow on the mind of citizens. A terrorist usually takes on a bifurcated method of recognizing its victims, it uses the bilateral thought that either something/someone is good or bad, but there is not even a single grey region. This way of viewing the things leaves no space of uncertainty in minds of victims, and so it makes easier for them to execute the opponents without any shame. Strikes of the drones have taken lives and disfigured a large number of innocent citizens in the backward areas of Pakistan (Adnan \& Fatima, 2018). These activities have enraged the individuals, and all this is forcing them to make use of arms against their supposed invaders. The way in which the kith and kin of the dead are prompted and engaged in such actions is quite common in Pakistan, and can last for years to come. Like many developing countries of the world, corruption enjoys the status of endemic in Pakistan.

Nevertheless, in Pakistan it is so rampant that this country stands at the highest position in world ranking (Haider, 2019). A survey showed that Pakistan stands on 139th position among other corruption free states. The conditions within country have also proved that administration is heavily constrained with it. Different case studies, the historical accounts, news reports, and surveys have showed that prevalence of corruption at all levels (Pellegrini, 2011, Menocal, Taxell, Johnsøn, Montero, Simone \& Tobias, 2015). In Pakistan, it has already become a predominant way of life, and all this is resulting in the inefficacy of its institutions. All this is leading to view that corruption is increasing day by day and people are becoming more and more immune to this endemic. It is prevalent in every sector, organization, and institution of country, reiterates same idea of its prevalence in all institutions (Nicholas, Kehinde, Imhonopi \& Evbuoma, 2016). Whenever a citizen comes in contact with bureaucracy, he has to face corruption no matter how bigger or smaller the task is and all this highlights the prevalence of this problem faced by the public (Lewis, 2017). Naviaux, (2018) views that social health protection being a crucial element aims at reducing hurdle and sharing load which results in access to health services in particular areas.

Likewise, government also spends money for the distribution of essential health services which aims to reduce burden of disease in industrious years of life. The Human Conditions in 2003 and also shows that malnutrition is a big problem in this country. Their reports show that $40 \%$ of children under the age of 5 years are malnourished. The malnourishment results in deaths of $50 \%$ of children who are under the age of five (Asim \& Nawaz, 2018). Education plays a crucial role in national development by creating sense of liability in citizens. It helps them in achieving their individual, societal and national rights and performing their duties. It aims at enabling the people by increasing their consciousness as the global citizen which in turn creates feeling of cooperation and trust. Education plays a role in promotion of the economic development which ultimately results in prosperity and performance of roles of citizens in national development (Gardiner, 1994; Hughes, 2004; Petrick, 2010; Wahyudin \& Suwirta, 2017). Pakistan being one of the developing countries lacks a strong economy, and political stability. It is facing a lot of the troubles in the form of militarism, political turmoil, social instability, violence, and economic 
degradation and other important factors which all results from the weak education system in country.

According to UNICEF and Save the Children, 2005, Pakistan is facing problems like militarism, insecurity, and poverty. All these problems stem from the illiteracy and lack of awareness, and tolerance which result from weak education system (Ahmad, 2014). In Pakistan, the role of the education was not given its due importance and it resulted in slow development of country. The quality of education has not been established since the creation of this country and the allotment of low budget to this sector in each government has resulted in the deterioration of this field. All this resulted in the education system which is failing to help the country socially, politically and economically. Though many years have passed and almost the 25 educational policies have been made but this system is still failing to help the nation socially, politically, and the economically (Shrestha et al., 2019). The factors which are contributing in making these conditions worse are; the governmental non-seriousness, poor infrastructure, mismanagement, and irregular policies. Investment of both types; external and internal, can play crucial role in revival of economy of Pakistan but the question of downfall of economic conditions of Pakistan remains unanswered. The main aim of this paper is to highlight the effects of the poor conditions of law and order in investment opportunities and emphasis on investment in Pakistan for the revival of the national economy.

The implementation of laws and rules provides ministrations, offices, and facilities. Governance is action on the wishes and not the goals set by principal (Fukuyama, 2013). The political signals like, social and economic conditions, law and order, governmental stability, bureaucracy, ethnic stress, democracy and corruption, contribute in calculating political governance and so it cannot deny the view that politics and governance are interlinked. Politics is a way of governing wherein different decisions are implemented to take control, which concerns actors of state influenced by ideological principles focusing on provision of benefits through organizational membership. So, in way civil servants are considered as non-political and politicians as political. Yet, different institutions like, army, courts, and police are considered public due to their accountability for organization of social life (Adnan \& Fatima, 2018). These situations have made the conditions worse for LEAs within Pakistan like; the police are not equipped and trained to deal with such militant activities. The official figures of militant activities are lower as compared to unofficial figures. Yet we depend on data given to us in report on National Public Safety Commission by National Police Bureau (Crow \& Lawlor, 2016). Frames are used to structure/organize meaning of message.

They are commonly used to frame the media and news. They influence perception of audience and in a way act as a variety of agenda setting where they instruct the people to what and how think about a specific issue and in a way act as agenda setting (Scheufele, 1999). Entman, (2007) Framing involves portraying narrative and description to the addressees that leads to a required construal of apparent reality by stressing some of the aspects of an issue while ignoring the other aspects, and suggesting linkages among them (Bashatah, 2017). Scholars regard framing as the contrast between "frame in communication or media frame" and "frame in thought or individual frame" (Mpalirwa, 2015). News about an event or issue conveyed to the public, including words, arguments, imageries, and demonstration-style used by the media house or agency. The gatekeeping choices determine the relevance, significance, and appropriateness or vice versa, the information becomes obvious in the following frames. The next term "frame in thought, or an 
individual frame", still, what individual from the target audience perceives to be most relevant, significant, feature of relayed news (Chong \& Druckman, 2007). This dichotomous concept of the term "frame" is paramount to development of the frame and frame setting (Crow \& Lawlor, 2016).

\section{Research Question}

What comparison of the government's performance through the framing analysis of news stories on the general issues by selected newspapers is the main theme of the current study that need investigation.

\section{RESEARCH METHODOLOGY}

The investigator applied quantitative content analysis. This method was adopted to explore 7 the picture on7the basis7of contents. For this7purpose, the researchers examined the issue on the bases of the Media Agenda and to evaluate the performances of the PML-N (2013 to 2018). The population7for this7studywere all news stories related to general issues which were published in daily Dawn, The News, The Nation, and Daily Times. All news stories related to general issues were published in the selected newspapers from 2013 to 2018 in Pakistan had been analysed. The type of the study content analysis and the census method were applied to investigate the problem. For example, the newspaper, it might be geo Figure situation distribution, frequency, readership, source, etc. consequently, it was decided to select the population through census technique.

\section{RESULTS OF STUDY}

A number of issues were discussed with relevant references and resources but now also discuss the micro issue which leads to macro issue for example; the Terrorism category divided into five sections, i.e., the state-sponsored terrorism, dissent terrorism, terrorists and the left and right, the religious terrorism and criminal terrorism. Consequently, in this study try to accumulate the different issues which are the core exploration of the current study, which include: terrorism, corruption, health, education, law and order and the others related problems (belongs to this governments). The news related to issues and sub-issues published in the selected newspaper (The Dawn, The News, The Nation and Daily Times) from 2013 to 2018 in Political Regime of PML-N.

\section{Table 1}

Framing of News Stories in Newspapers During 2013 to 2018

\begin{tabular}{lcccccc}
\hline & \multicolumn{2}{c}{ The Dawn } & \multicolumn{2}{c}{ The News } \\
\hline Issue & $\begin{array}{c}\text { Good } \\
\text { Governance }\end{array}$ & $\begin{array}{c}\text { Bad } \\
\text { Governance }\end{array}$ & Total & $\begin{array}{c}\text { Good } \\
\text { Governance }\end{array}$ & $\begin{array}{c}\text { Bad } \\
\text { Governance }\end{array}$ \\
\hline Terrorism & $1197(60.00)$ & $798(40.00)$ & 1995 & $1283(55.32)$ & $1036(44.67)$ & 2319 \\
Corruption & $777(60.00)$ & $518(40.00)$ & 1295 & $866(55.02)$ & $708(44.98)$ & 1574 \\
Health & $626(59.96)$ & $418(40.03)$ & 1044 & $692(61.56)$ & $432(38.44)$ & 1124 \\
Education & $606(60.00)$ & $404(40.00)$ & 1010 & $718(63.53)$ & $412(36.47$ & 1130 \\
Law \& Order & $596(60.02)$ & $397(39.98)$ & 993 & $700(61.24)$ & $443(38.76$ & 1143 \\
Other & $345(60.00)$ & $230(40.00)$ & 575 & $358(60.47)$ & $234(39.53)$ & 592 \\
\hline
\end{tabular}


Amin et al... Reframing The Debate: Agendas

Table 1a

Framing of News Stories in Newspapers During 2013 to 2018

\begin{tabular}{lcccccc}
\hline & \multicolumn{2}{c}{ The Nation } & \multicolumn{2}{c}{ Daily Time } \\
\hline Issue & $\begin{array}{c}\text { Good } \\
\text { Governance }\end{array}$ & $\begin{array}{c}\text { Bad } \\
\text { Governance }\end{array}$ & Total & $\begin{array}{c}\text { Good } \\
\text { Governance }\end{array}$ & $\begin{array}{c}\text { Bad } \\
\text { Governance }\end{array}$ & Total \\
\hline Terrorism & $691(58.91)$ & $482(41.09$ & 1173 & $896(45.00)$ & $1095(55.00)$ & 1991 \\
Corruption & $472(65.56)$ & $248(34.44)$ & 720 & $598(50.00)$ & $731(55.00)$ & 1329 \\
Health & $288(58.30)$ & $206(41.70)$ & 494 & $470(45.02)$ & $574(54.98)$ & 1044 \\
Education & $275(56.47)$ & $212(43.53)$ & 487 & $469(45.01)$ & $573(54.99)$ & 1042 \\
Law \& Order & $295(57.28$ & $220(42.72$ & 515 & $462(44.99)$ & $565(55.01)$ & 1027 \\
Other & $156(80.83)$ & $37(19.17)$ & 193 & $274(45.07)$ & $334(54.93)$ & 608 \\
\hline
\end{tabular}

During Political Regime PMLN (2013 to 2018) the framing of news about the general issue, in Table 1 The Dawn published the 1197 news regarding terrorism as good or controlled, and 798 published the news as bad or negative. The news published 1283 news as good or controlled and 1036 as bad or negative response of governance. The Nation published the 691 news as good or controlled and 482 as bad or negative. Daily Times published the 896 news as good performance or controlled and 1095 as bad performance or the negative response. A further main issues in Pakistan is Corruption in table 1 the number of cases which were registered in Political Regime PMLN (2013 to 2018). The Dawn published the 777 news as good and 518 as bad performance in 2013 to 2018. The news published the news on the same issue (Corruption) is 866 as a good and 708 news are published as bad performance or fail to control the corruption. The Nation published the 472 news as good performance and controlled and 248 news as a bad performance and uncontrolled. And last Daily Times published the news 598 as a good and 731 as bad or negative. Third issue in table 1 is health which shows different figures in times span (2013 to 2018).

A healthy nation is not only valued in its own right, but it also raises the human capital of a country, thereby contributing to the economic and social development. The Dawn newspaper published the 626 news as good or controlled and 418 as bad or uncontrolled on health issue. The News newspaper published the 692 as good or controlled and 432 as bad or uncontrolled. The Nation newspaper published the 288 as good or controlled and 206 as bad or uncontrolled. Daily Time newspaper published the 470 as good or controlled and 574 as bad or uncontrolled. The fourth issue is education, in Table 1 The Dawn published the 606 news regarding education as good or controlled, and 404 published the news as bad or uncontrolled. The news published the 718 news as good or controlled and 412 as bad or uncontrolled response of governance. The Nation published 275 news as good or controlled and 212 as bad or uncontrolled. Daily Times published the 469 news as good performance or the controlled and 573 as bad performance or uncontrolled response. A main supplementary issue is Law and Order situation in Pakistan show in table 1 discussed in political regime PML-N (2013 to 2018) by selected newspaper of the study.

The Dawn published the 596 news as good and 397 as bad performance in 2013 to 2018. The news published the news on the same issue (Law and Order) is 700 as a good and 443 news are published as bad performance or fail to control the Law or order situation. The Nation published the 295 news as good performance and controlled and 220 news as a bad performance and 
uncontrolled. And last Daily Times published news 462 as a good and 565 as bad or controlled. The political instability and political victimization are a part of every government. In table 1 , The Dawn newspaper published the 345 news as good or controlled and 230 as bad or uncontrolled on other issues. The News newspaper published the 358as good and 234 as bad. The Nation published 156 as good and 37 as bad. Daily Time newspaper published 274 as good and 334 as bad.

Table 2

Pearson Correlation related to Issues in Political Regimes (PMLN) from 2013 from 2018

\begin{tabular}{lcccccc}
\hline & Terrorism & Corruption & Health & Education & Law \& Order & Others \\
\hline Terrorism & 1 & $.999^{* *}$ & $.982^{*}$ & $.987^{*}$ & $.994^{* *}$ & 0.947 \\
Corruption & $.999^{* *}$ & 1 & $.976^{*}$ & $.984^{*}$ & $.993^{* *}$ & 0.94 \\
Health & $.982^{*}$ & $.976^{*}$ & 1 & $.998^{* *}$ & $.994^{* *}$ & $.989^{*}$ \\
Education & $.987^{*}$ & $.984^{*}$ & $.998^{* *}$ & 1 & $.998^{* *}$ & $.985^{*}$ \\
Law \& Order & $.994^{* *}$ & $.993^{* *}$ & $.994^{* *}$ & $.998^{* *}$ & 1 & $.974^{*}$ \\
Others & 0.947 & 0.94 & $.989^{*}$ & $.985^{*}$ & $.974^{*}$ & 1 \\
\hline
\end{tabular}

**. Correlation is significant at the 0.01 level (2-tailed).

*. Correlation is significant at the 0.05 level (2-tailed).

The Pearson correlation was applied wherein this technique which is run on SPSS to analyses and identify the comparison and effect among on the variable which is used in the study. Table 2 provides analysis of path analysis in which comparison specify estimate. The result Pearson reflected the acceptance and not supported of the hypothesis. In the current study, the general issues and Selected Newspapers intensity have been taken as the independent variables, And, Political Party (PML-N) spending has been taken as dependent and has been taken as mediating variable. The empirical results show that the correlations in Political Regimes (PMLN) from 2013 from 2018 by selected newspaper, i.e., "The Dawn", "The News", "The Nation" and "Daily Times".

\section{Figure 1}

Overall Performance of Government (PML-N)

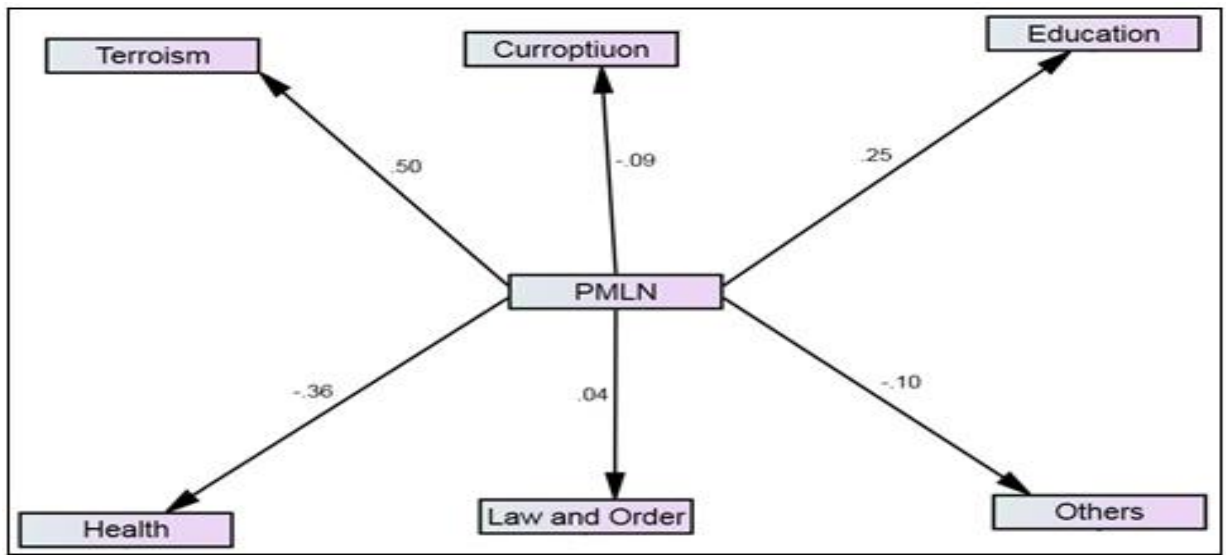


The Graphic 1 shows that the overall performance of the government (PML-N) is good and bad performance to control overall issues in Pakistan during his regime. In figure 1, illustrated that the terrorism is (.50) Corruption (-.09) Education (.25) Health (-.18), Law and Order Situation (.04) and Others issue (-.10). Thus, it can understand that comparison between the issues and political parties have direct relations and consumption by Sleeted Newspaper after introducing materialism in the model. The overall coverage and significant difference between value of chisquare regarding general issues of the study in selected newspapers are (Chi-Square $=5.938$; $\mathrm{P}$ Value $=0.204$ to "Terrorism", Chi-Square $=6.454$; P-Value $=0.168$ "Corruption", Chi-Square $=$ 13.395; P-Value $=0.004$ to "Health", Chi-Square $=19.930$; P-Value $=0.001$ to "Education", ChiSquare $=6.600 ; \mathrm{P}-$ Value $=0.159$ to "Law and Order", Chi-Square $=10.821 ; \mathrm{P}-$ Value $=0.029$ to "Others).

\section{Tables 3}

Overall Coverage and Significant Difference

\begin{tabular}{ccc}
\hline Pearson Chi-Square & Value & Asymp. Sig. (2-sided) \\
\hline Terrorism & $5.938^{\mathrm{a}}$ & .204 \\
Corruption & $6.454^{\mathrm{a}}$ & .168 \\
Health & $13.395^{\mathrm{a}}$ & .004 \\
Education & $19.930^{\mathrm{a}}$ & .001 \\
Law and Order & $6.600^{\mathrm{a}}$ & .159 \\
Other & $10.821^{\mathrm{a}}$ & .009 \\
\hline
\end{tabular}

\section{DISCUSSION}

Pakistan faced the most horrible situation with numerous issues such as terrorism, Afghan war, international pressure (economic sanctions) and other governance issues, which are alarming threat to prosperity of our country. The terrorist attacks hit all over Pakistan, especially in large and economically developed cities including Lahore, Peshawar, Rawalpindi, Multan, Karachi, Hyderabad and Quetta. Terrorists not only do bomb blast but also try to influence the existing authority to change their national policy and do reforms in the constitution of Pakistan. In last phase, the then PM Nawaz Sharif focused its attention on peace talks with militant outfits, that were failed to achieve the desired results and thus operation Zarb-e-Azab was initiated. So, these attacks not only killed soldiers, civilians and religious and political identities but also economic growth of Pakistan. In this era, Pakistan faces an insurgency in Karachi in the shape of political victimization. Pakistan faced all type of terrorist attacked i.e., funded terrorism, cyber terrorism, religious terrorism, sectarian terrorism, left-wing and right-wing terrorism. Several people hold view that Pakistan land has performed role of reserve for terrorists, but all this cannot mitigate reality that all this destruction has caused considerable damage of lives and financial revenue. These circumstances supply a productive ground for the growth of terrorism (Adnan \& Fatima, 2018).

The report was published that highlighted that terrorism affects Rs.78billions dollars from the Pakistani economy in the last ten years. Another pinpoint issue in Pakistan that is a corruption. Pakistan is still hostile against corruption and launched campaign "Say No To Corruption" in allover Public and Private Departments of Pakistan. The National Accountability Bureau (NAB) highlighted in its Annual According to TCI (Transparency International Index) the corruption index is low in PML-N Regime the Pakistan is standing on 19th uppermost in 175 countries. Like 
many developing countries of the world, corruption enjoys status of endemic in Pakistan. But, in Pakistan it is so rampant that this country stands at the highest position in the world ranking. (Adnan \& Fatima, 2018; Haider, 2019). Pakistan stands 139th position among other corruption free states. Third issue is health According to selected Pakistani newspapers in during political regimes in PML-N regime, situation regarding the health issue is not good but PML-N slightly controlled over health issues in the period. The performance regarding health issues in PML-N Regime from 2013 to 2018 overall total $32 \%$ health services provided by government in Pakistan and in Punjab the health service condition is $27 \%$ it means this performance is neither good nor bad.

Human Conditions in 2003 shows that malnutrition is big problem in this country. Their reports show that $40 \%$ of children under the age of 5 years are malnourished. The malnourishment results in deaths of $50 \%$ of children who are under the age of five (Asim \& Nawaz, 2018). Forth issue is education. The government formulated policy to develop a powerful institution that can control the higher education in the Pakistan called Higher education Commission (HEC) that helped the education sector make huge strides. Later on, HEC also became a victim of political turmoil. So, the last regime is PML-N from 2013 to 2018 the education policy according to DAILY TIMES-2018 the education crisis due to bad policy of PML-N but the, on the other hand, THE DAWN-2018 said PML-N was somehow serious about education. So, in this perspective, especially in Punjab government worked and introduced the DANISH SCHOOL SYSTEM for low-income families who could not afford education for their children and also provided the free book and uniform as well. All these problems stem from illiteracy and lack of awareness, and tolerance which result from weak education system (Ahmad, 2014; Crow \& Lawlor, 2016) In Pakistan, role of education was not given its due standing and resulted in slow development of country.

The quality of education has not been established since creation of this country and allotment of low budget to this sector in each government has resulted in the deterioration of this field. Fifth issue is law and order that shows several issues that corruption, embezzlement, terrorism and administrative authority were indulged in bad governance, but numbers of law-and-order issues were reported in selected newspaper. As well as PML-N government (2013 to 2018) have control over by help of Pak Army different types of internally surgical mission and also control the intense law and order situation especially in urban and ruler cities of Pakistan. The factors which are contributing in making these conditions worse are; governmental non-seriousness, poor infrastructure, mismanagement, and irregular policies. Investment of both types can play crucial role in economic revival of Pakistan but the question of downfall of economic conditions of Pakistan remains unanswered. The paper highlights the effects of poor conditions of law and order, and emphasis on investment in Pakistan for the revival of economy (McNair, 2017). And last issues were related with the consisting of Political Instability and Political Victimization in Pakistan.

In this study, the selected newspaper, i.e., The Dawn, The News, The Nation and Daily Times in three political regimes. And PML-N (2013 to 2018) day first have allegation to highjack the election 2013 as a raged election Especially from PTI and Other issues Political parties, as well as PML-N, faced corruption charges and PM Nawaz Shareef accused corrupted along with his family nominated in PANAMA Leaks. These situations have made the conditions worse for LEAs within Pakistan like; the police are not equipped and trained to deal with such militant activities. 
Amin et al... Reframing The Debate: Agendas

The official figures of the militant activities are lower as compared to unofficial figures. Yet we depend on data given to us in report on National Public Safety Commission by National Police Bureau.

\section{CONCLUSION}

This study especially was designed to investigate political regime of PML-N (2013 to 2018) that how much their performance was affected through news coverage. And, to evaluate performance regarding the general issues, its policies to control and provide a better living style and safety to public. Performances of these selected regimes evidently by selected mainstream newspapers' coverage of Pakistan, i.e., The Dawn, The News, The Nation, and Daily Times. The finding of the study showed that terrorism does not only do a bomb blast but also try to influence existing authority to change their national policy and do reforms in the constitution of Pakistan. These attacks killed not only soldiers, civilians, and religious and political identities but also economic growth of Pakistan. Graphic 4.2.5 explain that terrorism issue in Pakistan Muslim League-N. The terrorist lowest attacks hit all over Pakistan, especially in large and economically developed cities includes Lahore, Peshawar, Rawalpindi, Multan, Karachi, Hyderabad and Quetta in PML$\mathrm{N}$ Regime from 2013 to 2018. And Pakistan faced armed forced almost eliminated the terrorist, especially in KPK province. Political Parties not seem serious to become creditable to the ruling party and continued to hold the government responsible for every failure of democratic norms and procedure the continued throughout the period contest between two parties that is PPP and PML-N for political power they're tactical at times threaten to derail the fragile democracy of Pakistan. But the democratic government were failed to deliver their promises whom they made before election in terms of tackling the issues, i.e., terrorism, corruption, health, education and etc.

\section{REFERENCE}

Adnan, M., \& Fatima, B. (2018). Political, Economic and Social Governance in Pakistan: Its Practices and Issues. Journal of the Research Society of Pakistan, 55(1).

Ahmad, I. (2014). Critical Analysis of Problems of Education in Pakistan: Possible Solutions. International Journal of Evaluation and Research in Education, 3(2), 79-84.

Asghar, M. U. (2013). The Governance Issues in Pakistan: The Suggested Action Strategy. ISSRA PAPERS, 113.

Asim, M., \& Nawaz, Y. (2018). The Child malnutrition in Pakistan: Evidence from literature. Children, 5(5), 60.

Bashatah, N. S. (2017). Framing analysis of British newspaper representation of Saudi women from 2005-2013 (Doctoral dissertation, University of Salford).

Chattopadhyay, D. (2018). Gatekeeping Breaking News Online: How Social Media Affect Journalists' Crime News Sourcing and Dissemination in India (Doctoral dissertation, Bowling Green State University).

Chong, D., \& Druckman, J. N. (2007). Framing Theory, URL: https://www. annual reviews. org/doi/ full/10, 1146.

Crow, D. A., \& Lawlor, A. (2016). Media in the policy process: Using framing and narratives to understand policy influences. Review of Policy Research, 33(5), 472-491.

Entman, R. M. (2007). Framing bias: Media in the distribution of power. Journal of communication, 57(1), 163-173. 
Gamson, W. A., \& Modigliani, A. (1989). Media discourse and public opinion on nuclear power: A constructionist approach. American journal of sociology, 95(1), 1-37.

Gardiner, L. F. (1994). Redesigning Higher Education: Producing Dramatic Gains in Student Learning. ASHE-ERIC Higher Education Report No. 7. ERIC Clearinghouse on Higher Education, One Dupont Circle, NW, Suite 630, Washington, DC 20036-1183.

Haider S. A. (2019). Impact of Corrupt Actions on Project Performance in Construction Industry (Doctoral dissertation, Department of Management Science, The COMSATS University Islamabad, Lahore Campus).

Hoffert, C. R. T. (2018). The Divided Bias: The Media Framing of the Healthcare in the 2016 Presidential Campaign.

Hughes, J. (2004). Citizen cyborg: Why democratic societies must respond to the redesigned human of the future. Basic Books.

Knox, J. (2017). Data power in education: Exploring critical awareness with the "Learning Analytics Report Card”. Television \& New Media, 18(8), 734-752.

Lateef, K. S. (2016). The Evolution of the World Bank's thinking on governance. The Report issued. ISSRA PAPERS.

Lewis, J. (2017). Social impacts of corruption upon community resilience and poverty. Jàmbá: Journal of Disaster Risk Studies, 9(1), 1-8.

Liu, J. (2017). The Role of Media in Promoting Good Governance and Building Public Perception About Governance: A Comparison of China and The United States.

McNair, B. (2017). An introduction to political communication. Taylor \& Francis.

Menocal, R. A., Taxell, N., Johnsøn, J. S., Montero, A. G., Simone, F., \& Tobias, J. (2015). Why corruption matters: Understanding causes, effects and how to address them. Evidence Paper on Corruption, Department for International Development.

Mpalirwa, D. (2015). Asking for It: Evaluating the Framing of the Sexual Violence Epidemic in South Africa.

Naviaux, R. (2018). Antipurinergic therapy for autism-An in-depth review. Mitochondrion, 43, 1-15.

Nicholas, O. S., Kehinde, O. J., Imhonopi, D., \& Evbuoma, I. K. (2016). Good governance and leadership: Pathway to sustainable national development in Nigeria. Journal of Public Administration and Governance, 6(1), 35-49.

Pavelka, J. (2014). The factors affecting the presentation of events and the media coverage of topics in the mass media. Procedia-Social and Behavioral Sciences, 140, 623-629.

Pellegrini, L. (2011). The rule of the jungle in Pakistan: A case study on corruption and forest management in Swat. In Corruption, Development and the Environment (pp. 121-147). Springer, Dordrecht.

Petrick, J. A. (2010). Sustainable stakeholder capitalism and redesigning management education: Lessons generated from the great global recession. Journal of Corporate Citizenship, (40), 101-126.

Riffe, D., Lacy, S., Fico, F., \& Watson, B. (2019). Analysing media messages: Using quantitative content analysis in research. Routledge.

Scheufele, D. A. (1999). The Framing as a theory of media effects. The Journal of communication, 49(1), 103-122.

Scheufele, D. A., \& Tewksbury, D. (2007). Framing, agenda setting, and priming: The evolution of three media effects models. Journal of communication, 57(1), 9-20.

Scheufele, D. A., \& Tewksbury, D. (2007). Framing, agenda setting, and priming: The evolution of three media effects models. Journal of communication, 57(1), 9-20. 
Schildkraut, J., \& Gruenwald, J. (2019). Media salience and frame changing in the coverage of mass shootings: a comparison of ideological and non-ideological attacks. Journal of criminal justice and popular culture, 19(1), 62-89.

Shrestha, U., Williams, T. P., Samarrai, S., Geldermalsen, A., \& Zaidi, A. (2019). What is the relationship between politics, education reforms, and learning? Evidence from a new database and nine case studies.

Spalding, A. B. (2017). Freedom from Official Corruption as a Human Right.

Tetteh, D. A., \& King, J. M. (2011). Newspaper coverage of the US healthcare reform debate: A content analysis. Business Research Yearbook, 18(2), 503-510.

Trainor, J. E., \& Subbio, T. (2014). Critical issues in disaster science and management: a dialogue between researchers and practitioners. FEMA Higher Education Project.

TUTHERIDGE, G. (2017). What is the role of gatekeeping journalist's in today's media environment?

Wahyudin, D., \& Suwirta, A. (2017). The Curriculum Implementation for Cross-Cultural and Global Citizenship Education in Indonesia Schools. EDUCARE, 10(1).

Welbers, K. (2016). Gatekeeping in the digital Age. Amsterdam: Vrije Universiteit. Retrieved on, 2. 